\title{
Selecting honey bees for resistance to Varroa jacobsoni
}

\author{
John R. Harbo*, Jeffrey W. Harris \\ USDA-ARS, Honey Bee Breeding, Genetics and Physiology Laboratory, \\ 1157 Ben Hur Road, Baton Rouge, LA 70820, USA
}

(Received 16 September 1998; accepted 8 February 1999)

\begin{abstract}
This report describes a systematic approach to selecting honey bees (Apis mellifera $\mathrm{L}$.) for resistance to Varroa jacobsoni Oudemans. The equation $\left(P_{1}(a b)^{n}=P_{2}\right)$ describes the growth of the mite population in a colony of honey bees that has a constant supply of worker brood. $P_{1}$ and $P_{2}$ are the initial and final mite populations, $a$ is population change whilc mites are in brood cells, $b$ is population change outside brood cells and $n$ is the number of reproductive cycles of the mite. By comparing the growth of mite populations in each colony $\left(P_{/} / P_{1}\right)$, one can determine which bees are more resistant to mites. The values of $a, b$ and $n$ provide details about the growth of the mite population by identifying which portion of the mite's reproductive cycle was affected. Selection should be based on specific characteristics of bees rather than on general changes in mite populations. When specific characteristics of bees affect different components of the reproductive cycle of the mite, it may be possible to combine the characteristics to produce bees that are more resistant to mites. (1) Inra/DIB/AGIB/Elsevier, Paris
\end{abstract}

Apis mellifera / mite / Varroa jacobsoni / resistant population / selective breeding

\section{INTRODUCTION}

This report is a review of our approach to select honey bees (Apis mellifera L.) for resistance to Varroa jacobsoni Oudemans (Acari: Varroidae). We outline a systematic approach which should be effective in any selection program that involves characteristics of honey bees that are measured at the colony level.
We define mite resistance as the ability of a colony of honey bees to impede the growth of a population of $V$. jacobsoni. With this definition, a highly resistant colony of bees would cause a mite population to decline and then to either disappear or be maintained at a very low level. This is the breeding objective. However, during the breeding process, especially at the beginning, a breeder may select colonies that measur-

\footnotetext{
* Correspondence and reprints

E-mail: jharbo@asrr.arsuda.gov
} 
ably slow the growth of their mite populations but would eventually die from the mite infestation. These susceptible colonies with resistant characteristics can be important in the selection process, especially in difficult selection projects (such as resistance to $V$. jacobsoni), and accurate measurements are needed to identify the colonies that are slightly better than others. Therefore, selective breeding of bees for resistance to $V$. jacobsoni relies on our ability to accurately measure and describe the growth of mite populations within colonies of bees.

The first step in selective breeding is to choose a population of bees within which to work. It is best if this population contains some colonies with the desired phenotype (in this case resistance to mites), but the population may express only low levels of resistance, or even undetectable levels. For example, the importation of bees from far eastern Russia [11, 51] is the beginning of a breeding program that began with stock that already contained some of the desirable qualities.

In bee breeding, man can do things that nature cannot do. These are: 1) special mating schemes (e.g. single drone inseminations or inseminating many queens with the same mixture of semen); 2) the ability to focus selection on one characteristic at a time; and 3) the ability to select susceptible colonies that contain characteristics of resistance (colonies that would eventually die in nature). There is no need for colonies to die in a breeding program that selects bees for resistance to mites.

The use of single-drone inseminations may be important at the beginning of a selection program, especially when selecting for colony traits that are present at low frequencies. When a queen is mated to semen from a single drone, worker bees in the colony all have identical genetic material from their father, who is represented by identical spermatozoa that are now in the spermatheca of the queen. Thus the worker bees in such colonies are more closely related than normal sisters and have a relatedness of 0.75 . The use of single-drone matings makes it easier to detect colony characteristics that may be masked by multiple mating, and it amplifies the differences among colonies $[26,55]$.

Advantage may shift to multiple-drone inseminations during the mid and latter stages of selective breeding [28]. The reasons are that: 1) queens survive longer when inseminated with multiple drones $[8,26]$; 2) more effective selection schemes can be used (such as mating a group of queens with the same mixture of semen); and 3) daughter queens from a multiply mated queen are more variable and would therefore reduce the rate of inbreeding at a time when the specific characteristic of selection is wellestablished.

We used the following sequence in our approach to breed bees for resistance to V. jacobsoni:

1) develop techniques for measuring populations of bees and mites and for measuring characteristics that are associated with resistance;

2) identify specific characteristics that are related to the growth of mite populations;

3) determine if these characteristics are heritable;

4) enhance heritable characteristics with selective breeding;

5) assemble resistant components into productive, mite-resistant bees.

\section{EVALUATION PROCEDURE}

\subsection{Establishing heritability}

It is important to calculate heritability $\left(h^{2}\right)$ of a desirable characteristic before beginning a program of selective breeding. Heritability $\left(h^{2}\right)$ is the proportion of the observed variance (among a group of bee colonies in this case) for which differences in heredity are responsible [35]. The estimate of $h^{2}$ is a pragmatic measurement that 
predicts breeding success. If a characteristic has an $h^{2}$ close to 1 , then the characteristic can be rapidly changed with selective breeding. If $h^{2}$ approaches 0 , selective breeding will probably fail. As a general rule, it is reasonable to attempt selective breeding if $h^{2}>0.25$.

We used sibling analysis [10] to estimate heritability of various characteristics of bees that may be associated with the growth of mite populations (table I, [27]). The heritability test consisted of 28 colonies with unrelated queens that had not been selected for resistance to $V$. jacobsoni. The relatedness of the colonies was established by inseminating groups of four queens with a single mixture of semen that had been collected from the drones produced by one queen. Seven such queens that served as drone mothers for the experiment were unrelated to each other and were unrelated to the queens that were inseminated. This produced seven groups of four colonies, with each colony related as a full sister to the other three colonies in its group and unrelated to the other 24 colonies [27].

\subsection{Three levels of evaluation and measurement}

We always measured the growth of a mite population within a colony of bees that was being evaluated for resistance. A field test is the core of the evaluation with the honey bee colony serving as the experimental unit in the analyses. The evaluation requires at least 10 weeks and measures growth of mite populations in a group of honey bee colonies and provides a framework for measuring other characteristics at appropriate times during the course of the

Table I. Heritability of colony characteristics based on sibling analysis of 28 colonies during a 70-day test period in Baton Rouge, Louisiana (15 May-24 July) [27]. Uniform, broodless colonies were established on 15 May from a large cage of mite-infested bees.

\begin{tabular}{lcc}
\hline Characteristic & Range of data & $h^{\mathrm{a}} \pm \mathrm{SE}$ \\
\hline Suppression of mite reproduction, June $2^{\mathrm{b}}$ & $8-52 \%$ & $0.38 \pm 0.58$ \\
Suppression of mite reproduction, June $23^{\mathrm{h}}$ & $15-48 \%$ & $0.06 \pm 0.48$ \\
Suppression of mite reproduction, July $24^{\mathrm{h}}$ & $9-48 \%$ & $0.46 \pm 0.59$ \\
Hygienic behavior & $4-91 \%$ & $0.65 \pm 0.61$ \\
Physical damage to mites (total) & $4-35 \%$ & $0.00 \pm 0.45$ \\
$\quad$ Dents in body & $1-11 \%$ & $0.00 \pm 0.45$ \\
Broken legs or bodies & $0-26 \%$ & $0.17 \pm 0.52$ \\
Capped period (h) & $268-290$ & $0.89 \pm 0.59$ \\
Proportion mites in brood & $39-82 \%$ & $1.24 \pm 0.49$ \\
Mites per 100 cells of brood (24 July) & $4-30.5$ & $0.28 \pm 0.56$ \\
Final mite population $^{\mathrm{d}}$ & $534-3389$ & $0.17 \pm 0.52$ \\
Mites per 1 000 bees (24 July) $^{\mathrm{e}}$ & $26-198$ & $0.01 \pm 0.46$
\end{tabular}

"The range of data from the 28 colonies in the test. This experiment was not designed to produce colonies that were highly resistant to mites.

${ }^{h}$ Suppression of mite reproduction combines the following three components: 1) dead foundress mite in a cell with no progeny, 2) live foundress mite with no progeny, and 3) live foundress mite with progeny produced too late to mature.

c The number of adult foundress female mites, based on counts of 200 cells of capped brood per colony.

${ }^{d}$ The mite population refers to the total number of adult female mites in the brood and on adult bees. Since all colonies started with the same number of mites, this is an expression of the growth of the mite populations (final population/original population).

'As above, mites refers to all of the adult female mites in the colony (including the foundress females in the brood cells). Bees refers to all adult bees in a colony. 
test. Characters that are affected by adult bees such as hygienic and grooming behavior cannot be measured until the population of adult bees becomes the progeny of the test queen.

We have described our procedure for field evaluation in detail [25, 27, 29]. In general, uniform populations of bees and mites are established by collecting about $30 \mathrm{~kg}$ of mite-infested bees into a large cage and then subdividing the bees into colonies that contain about $1 \mathrm{~kg}$ of bees, a queen to be tested and broodless combs. We calculated the initial mite populations by sampling bees from the large cage and by knowing the weight of the bees that we put into each colony. We simplified the growth model by using only worker-sized combs in the colonies.

Growth of the mite population was tested at three different levels of detail. The first level was the most general and was simply the change in the mite population from a starting point (time zero in a field test) to an ending point (in the first group in table II, the ending point was 70 days later). The mite populations in each colony at the beginning and end of the test were designated as $P_{1}$ and $P_{2}$, respectively. Population growth for the experimental period was thus $P_{2} / P_{1}$.

At the second level, we explain how a mite population went from $P_{1}$ to $P_{2}$ in terms of the three components of the mite's reproductive cycle that can affect the growth of a mite population. The equation is $P_{1}(a b)^{n}=P_{2}$. Population growth of mites is $(a b)^{n}$. These three components (described in figure I) are: 1) the change in the mite population while mites are in the brood cell $(a)$, which is the average number of adult female mites that leave a group of brood cells (adult daughters + living foundresses) divided by the number of foundresses that entered those cells; 2) the change in the mite population while mites are on adult bees $(b)$, which is the number of adult female mites that enter brood cells divided by the number that had emerged from brood cells in the previous cycle; and 3) the number of days needed to complete one reproductive cycle of the mite

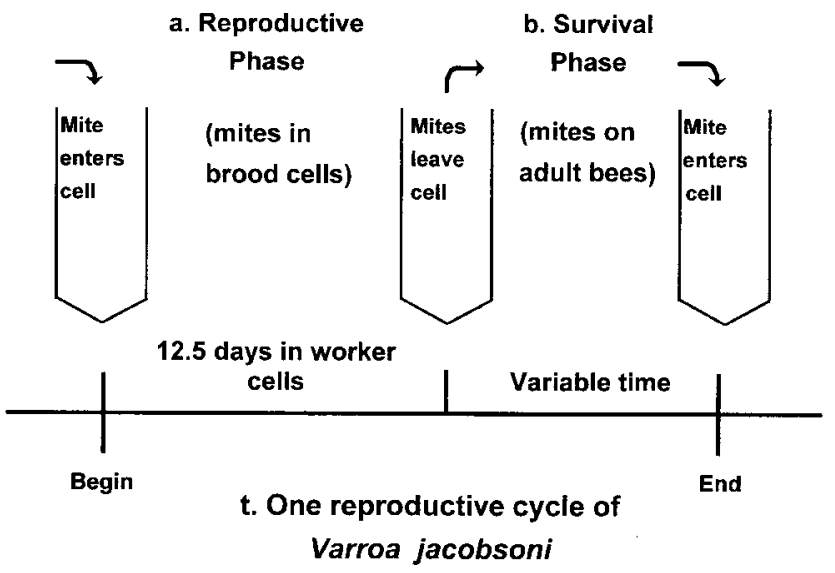

Figure 1. Three distinct components within a reproductive cycle of Varroa jacobsoni that affect the growth of a mite population. Any resistance mechanism of the honey bee that controls the growth of the mite population must exist in one or more of these components, and resistance at more than one component should have an additive effect. Component $a$ (in the brood cell) is the number of adult female mites that leave the brood cell divided by the number that enter. Component $b$ (outside the brood cell) is the proportion (ranging from 0 to 1 ) of female mites that survive to enter another cell. Component $t$ is the duration of the reproductive cycle. 


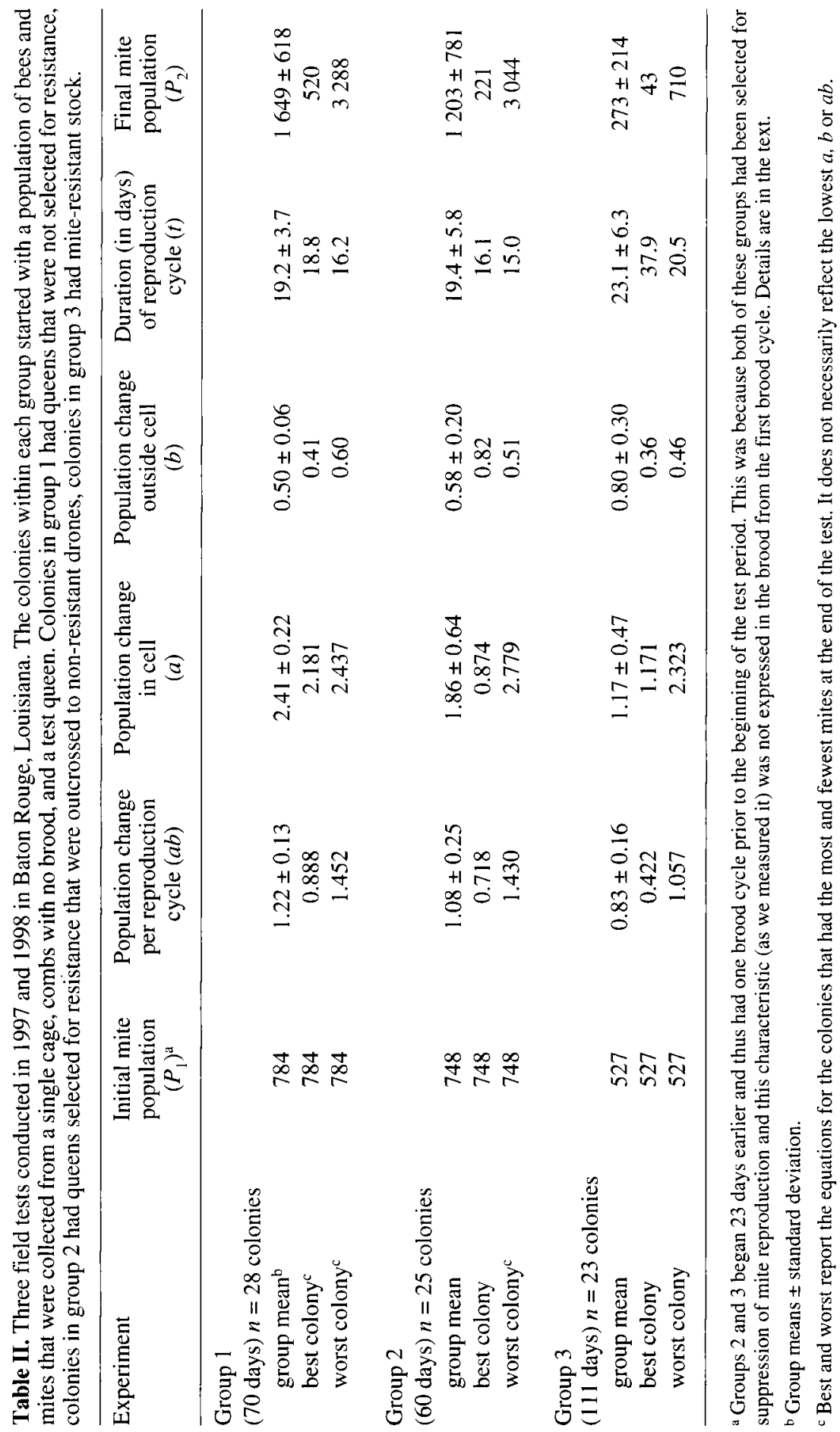


$(t)$, which is converted to $n$, the number of reproductive cycles during the evaluation period. All three factors are colony averages. Therefore, $a b$ ( $a$ times $b$ ) is the average population change per reproductive cycle, and multiplying $(a b)^{n}$ times the initial population $\left(P_{1}\right)$ equals the final mite population $\left(P_{2}\right)$. If any four of the five values are known, the remaining one can be calculated.

The product $a b$ is the average rate of population growth per reproductive cycle for a short test. During our short field tests $(10-15 \mathrm{wk})$ in which colonies begin with relatively low mite populations, the growth of the mite population probably follows the classic exponential growth curve, $P_{2}=P_{1} \mathrm{e}^{r t}$. In this equation $r$ is the intrinsic rate of increase per unit time and $t$ is the duration of the growth period. Exponential growth of $V$. jacobsoni populations occurs only for short periods of time and before the population reaches a carrying capacity. If $r$ is defined as 'per reproductive cycle' and $t=n$ (which is the number of cycles in a test), then $r=\ln (a b)$.

The third level of evaluation describes a specific characteristic that is measurable and heritable. We concluded [27] that this is the level at which one should select for resistance to $V$. jacobsoni. Each specific characteristic (described below) affects one of the three components described above ( $a$, $b$ or $t$ ). When specific characteristics affect the same component (for example suppression of mite reproduction and hygienic behavior both affect $a$ ), their combined effect may not be additive and may not be beneficial. However, when specific characteristics affect different components, they would probably combine to produce a colony with increased resistance to the mite.

\subsection{Specific characteristics of resistance to $V$. jacobsoni}

\subsubsection{Duration of capped period}

A brood cell is normally capped $\approx 8$ days after a fertilized egg is laid, and it remains capped for $\approx 12$ days until the worker bee emerges as an adult. However, among a group of colonies, there is significant variation in the average duration of the capped period, and this length of time is a heritable characteristic $[2,24,27,42-44]$. Bienefeld [2] also showed that the duration of the precapping period was affected by the genotype of the nurse bees. However, the duration of the capped period was affected by the genotype of the adult bees in the colony during the capped period but not by the genotype of the bees that had nursed them as larvae.

Büchler and Drescher [6] found a positive relationship between the duration of the capped period and the mite population in field colonies. Their data showed that about $25 \%$ of the variation in mite populations in their colonies could be explained by differences in the duration of the capped brood.

\subsubsection{Suppression of mite reproduction}

Mites that do not reproduce in the brood cell are found in nearly every colony. However, the frequency of non-reproducing mites in European honey bees is normally below $40 \%[9,14,16,21,32-34,36,37$, $40,47]$. We define non-reproducing mites as mites that enter the cell to reproduce but 1) produce no progeny, 2) produce males only, 3) produce progeny too late to mature, or 4) die in the cell before they can reproduce. Because non-reproduction of mites was found to be a heritable characteristic of bees [27], we call it suppression of mite reproduction. This characteristic is directly related to $a$ and has been linked to resistance to $V$. jacobsoni by many investigators $[1,9,15-17,23,38,52,53,58,62]$.

Data suggest that there may be two components that suppress mite reproduction. We (table $I$ ) evaluated both the immediate brood effects of this characteristic reported by Camazine [9] and a delayed expression of this characteristic. In the delayed expression, suppression of mite reproduction was not evident when mites went through their 
first reproductive cycle in colonies that would ultimately suppress mite reproduction about 2 months later. Fuchs [19] attributed this delayed effect to attributes that the mite attained before it entered a brood cell. Based on sibling analysis in table I, mite reproduction was heritable during our first observation. Therefore, larvae and/or pupae suppressed mite reproduction and this immediate effect, described by Camazine, was a heritable characteristic of bees. Mite reproduction had low heritability during the transition period (early July measurement in table $I$ ) but was again heritable at the third measurement. This third measurement was the delayed effect described by Fuchs [19] and the characteristic that we used as the basis of our selection (table $I I$ ).

\subsubsection{Entrapped mites}

We recently observed a higher frequency of foundress mites that were dead between the cocoon and the cell wall. When these were observed in cells with spinning bee larvae, we noticed that the entrapped mites were often alive. In most cases, the mites are found at the bottom of the cell, ventral side up, the same posture that they take while they are inactive in the brood food. In a 1997 field test, $27 \%$ of the foundress mites in the brood cells were entrapped [30]. However, we do not know if this characteristic is heritable. Martin [37] reports that about $1 \%$ of the foundress mites become entrapped, and we found similar levels of entrapment $(0.4 \%$ or $11 / 2930$ observations of foundress mites) in unselected colonies of bees in table II, group 1.

This characteristic is more effective in reducing mite populations than suppression of mite reproduction because a non-reproducing mite that survives has an $a b$ of 1 , while an entrapped mite has an $a b$ of zero.

\subsubsection{Hygienic behavior}

Hygienic behavior is the rate at which adult bees remove dead or diseased brood from capped cells [56]. Spivak [60] has shown that this characteristic is related to resistance to $V$. jacobsoni, and table I [27] shows that hygienic behavior (when measured with freeze-killed brood) is heritable $\left(h^{2}=0.65\right)$. Hygienic behavior is an important characteristic for mite resistance in Apis cerana $[50,54]$ and resistance to other diseases of bees such as chalkbrood [22, 61] and American foulbrood $[56,57]$.

\subsubsection{Grooming behavior}

Physical damage to mites may be caused by the activities of adult bees [59], and this grooming behavior is a heritable characteristic of bees $\left(h^{2}=0.71\right)$ [41]. Caution should be used in deciding what damage to mites is actually caused by grooming bees. For example, we found that dents in the dorsal surface of the idiosoma often occurred while young adult mites were still in their brood cells [27], and not by the mandibles of grooming bees. Although self grooming and nestmate grooming are important mechanisms of resistance to $V$. jacobsoni for Apis cerana $\mathrm{F}$., it is a less important component of resistance for our western honey bee Apis mellifera L. [3, 4, 7, 13, 18, 48, 49].

\subsubsection{Proportion of mites in brood}

This is a measure of the duration of the reproductive cycle of the mite $[25,46]$, which is explained in more detail in section 2.4.1. Mites are either on adult bees (in a phoretic stage) or in the brood cells (in a potentially reproductive stage).

The proportion of mites in brood was found to be a highly heritable characteristic in bees $\left(h^{2}=1.24\right)$ [27]. This is sometimes called invasion of brood cells $[5,20,39]$. Perhaps mites with a low proportion of mites in brood and therefore those with longer reproductive cycles are less attracted to bee larvae and therefore are slower to enter brood cells. This may be best explained by the work of Trouiller et al. [63] who describe a chemical signal produced by bee larvae 
that attracts $V$. jacobsoni to the brood. Because of a direct effect on $t$, this characteristic may serve well in combination with characteristics that affect $a$ such as suppression of mite reproduction or hygienic behavior.

\subsection{Describing the reproduction of mites}

The most basic calculation is the overall growth of the mite population in each colony. This is simply the final mite population divided by the initial mite population $\left(P_{2} / P_{1}\right)$. By rearranging the equation $\left(P_{1}\right.$ $(a b)^{n}=P_{2}$ ), the overall growth of the mite population $\left(P_{2} / P_{1}\right)$ equals $(a b)^{n}$. The next step is to solve for $a b$ by calculating $n$.

\subsubsection{Measuring $\mathrm{n}$}

Before we calculated the number of reproductive cycles $(n)$, we needed to calculate the duration of the reproductive cycle of the mites in each colony. The duration of a reproductive cycle is the average time from when a mite enters a cell until it enters another cell (time spent in the cell plus time spent on adult bees). Not all mites will have the same time for their reproductive cycle and the length may change with the age of the mite. However, only the group average is important.

The duration of the reproductive cycle of the mite is almost entirely related to the variability of the time that the mites spend outside the brood cell. There is significant variation in the duration of the capped period of bee brood $[2,24,42]$ but this variation is only slightly greater than \pm 1 day in European honey bees. Mites enter the cell about $1 / 2$ day before the cell is capped and remain until the capping is removed by the teneral bee in the cell. Therefore, the reproductive stage of the mite is relatively constant at $\approx 12.5 \pm 1$ days or $1 / 2$ day longer than the capped period. In contrast, the time spent outside the cells can vary by more than a week (summarized by Fries et al. [17]). For example, if $65 \%$ of the mite population is in the brood (typical), then the average duration of the mite reproductive cycle in that colony is $12.5 / 0.65$ or 19 days. If $40 \%$ are in brood cells, the reproductive cycle extends to 31 days. A longer reproductive cycle slows the growth of mite populations.

We estimated the length of the reproductive cycle of mites $(t)$ for each colony by comparing the number of mites on adult bees with the number of mites in brood cells (both were measured at the end of the test period). The number of reproductive cycles in the test was then calculated from the estimate of the length of the reproductive cycle for mites in a colony (divide the duration of the experiment by the length of the reproductive cycle). However, most of our tests were initiated in bee colonies with no brood. Since mites cannot begin their reproductive cycle until bees have capped brood, the mites in a colony that begins with no brood were each assigned 23 days for their first reproductive cycle $(7+12.5+3.5$, which was 7 broodless days +12.5 days in brood + half of a normal phoretic period).

The worst colony in table II (group 1) is used as an example of calculating $n$. The test ran for 70 days and based on proportion mites in brood, the colony had a reproductive cycle $(t)$ equal to 16.2 days. Therefore, $n=1+(70-23) / 16.2=3.9$ reproductive cycles.

\subsubsection{Calculating ab}

As shown in figure $1, a b$ is the population growth of mites per reproductive cycle. An $a b$ of 1 equals no change in the mite population; numbers $>1$ indicate population increase and $<1$ indicate population decline.

For calculating $a b$ the equation becomes:

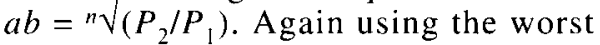
colony in table II, group 1 , as the example where $n$ was calculated as 3.9:ab=3.9 $\sqrt{4.19}$ $=1.45$. These data and the calculations can be handled on nearly any spreadsheet program. However, when using a computer it is simpler to write ${ }^{3.9} \mathrm{~V}\left(P_{2} / P_{1}\right)$ as $\left(P_{2} / P_{1}\right)^{(1 / 3.9)}$. 
However, we know that $a b$ is not always constant. Fuchs [19] showed that the major control of mite reproduction depended on events that occurred before the mite enters the cell. Harris and Harbo [27] have shown that colonies that suppress mite reproduction at a high rate may not express that characteristic in their first brood cycle when they have started with package bees. Thus, we not only assign the first brood cycle a standard length, we assign a standard $a b$ of 1.22 (the group average for unselected bees, group 1 in table II) when evaluating colonies for suppression of mite reproduction.

\subsubsection{Calculating a and b}

When $a b$ is already estimated, only one of the factors needs to be measured and the other can be calculated. We suggest measuring $a$, the rate of mite increase from the cell. We define $a$ as the sum of mature daughters and surviving mothers that exit the cells divided by the number of foundress females that entered those cells. Our $a$ differs from the rate of reproduction, which is the total number of progeny produced per mother mite $[15,31]$.

For table II, we calculated $a$ by observing mites in brood cells. We examined miteinfested cells when the bees were at the tan body stage (about 16-17 days after the bee egg was laid). In each cell we counted the number of foundresses and the number of female progeny that were deutonymphs or adults. We allowed each adult daughter and immobile deutonymph to have a $100 \%$ chance of reaching maturity and emerging from the cell, while each mobile deutonymph only had a $39 \%$ chance of doing so [21]. Therefore, our calculation of $a$ was (the number of live foundress females + the number of female progeny that were immobile deutonymphs or adults $+[0.39 *$ the number of mobile female deutonymphs])/the number of live and dead foundress females. Harbo [25] estimated $a$ by three different methods, and others have calculated $a$ by various techniques $[17,38]$.
There are also various ways to report $a$. Most report the number of female progeny that mature in a cell. Some do not include cells with mites that produce no progeny or cells with multiple foundresses. We include the contents of all infested cells, even those with dead foundresses. As described in the paragraph above, our $a$ included the surviving foundress. Since $98 \%$ of the foundress mites usually survive the reproductive phase, our estimates of $a$ are about 1 greater than the reproductive rate reported by many others.

An example of measuring $a$ and then separating $a$ and $b$ from $a b$ is again taken from the worst colony in table II, group 1 , where $a b$ had been calculated as 1.45 . We counted 20 mobile female deutonymphs, 38 immobile female deutonymphs, 28 adult daughters, 48 live foundresses and two dead foundresses. Therefore, $121.8 / 50$ equals an $a$ of 2.44 . Thus $b=a b / a$ or $1.45 / 2.44=0.60$.

What we call $b$ is not strictly survivorship outside the cell. It also includes mites that transfer into or out of the colony. When mite populations are relatively uniform, perhaps one can assume that immigration and emigration are equal. However, when adjacent colonies have highly variable populations of mites, drifting or robbing bees will probably tend to move mites into the colonies with fewer mites. This is a good argument for evaluating colonies that begin with uniform populations of bees and mites and for ending a field test as soon as possible.

\section{CONCLUSIONS}

It is certainly possible to breed bees that are resistant to V. jacobsoni. Table II (group 3) is an example of a group of 23 colonies that were selected for their ability to suppress the reproduction of mites in brood cells. Those colonies (as a group) averaged fewer mites at the end of the test than at the beginning [30]. However, breeding for resistance to $V$. jacobsoni has proven to be more dif- 
ficult than most other selection programs with bees, so it requires more precise measurements and a more systematic approach if one demands quick results.

There are presently many mechanisms of resistance that show promise. We think that the suppression of mite reproduction, hygienic behavior and proportion of mites in brood (the tendency for adult mites to not enter brood cells) are presently the three most promising of the specific characteristics that are heritable and should respond to selection.

It is important to note that there are locations around the world where honey bees survive without a program to control mites. Brazil is probably the best example [45]. Moreover, the levels of $V$. jacobsoni infestation in both European and Africanized bees in Brazil have further declined with time [12]. This suggests that when a population of bees is able to coexist with $V$. jacobsoni, natural selection will work on mites to make them less virulent, or selection will work on bees to make them more resistant. Both possibilities are likely. However, data suggest that mite populations in Brazil are less virulent than in most other parts of the world and that this virulence may be decreasing. Perhaps we can use this to our advantage. If we select bees to a point where they can survive reasonably well in the presence of mites, mites may respond by becoming less virulent.

Our strategy is to select bees that will retain an acceptable level of resistance when outcrossed to drones from non-resistant colonies. This would provide a broader genetic base for resistant bees, would preserve the genetic diversity of our honey bee populations, and would enable natural selection to operate more effectively. In this situation, a bee population would retain most of its genetic diversity as it gradually incorporates genes for resistance to mites.

Table II (group 2) is an example of queens from a mite-resistant stock that were out- crossed. The mite-resistant queens, selected for suppression of mite reproduction, were instrumentally inseminated with drones collected from colonies that had not been selected for resistance to mites. Some colonies were very good and expressed a high level of resistance, but others were highly susceptible. The group was variable. If a second specific characteristic of resistance was incorporated into this stock (such as a low proportion of mites in brood), a group of colonies with outcrossed queens may be more uniform and may be able to hold mite growth to an $a b$ of 1.0 or less.

\section{ACKNOWLEDGMENT}

We thank David Dodge, Daniel Winfrey, Shelley Savant and M. Shane Smith for their assistance. This work was supported, in part, by the Michigan Department of Agriculture and in cooperation with the Louisiana Agricultural Experiment Station.

\section{Résumé - La sélection d'abeilles melli-} fêres (Apis mellifera $\mathrm{L}$.) résistantes à Varroa jacobsoni Oud. Cet article examine les méthodes de sélection d'abeilles mellifères résistantes à l'acarien $V$. jacobsoni. Un plan de sélection est décrit ci-après, qui devrait être mis en cuuvre dans tout programme de sélection prenant en compte les caractères des abeilles mesurés au niveau de la colonie.

1) Développer des méthodes pour mesurer les populations d'abeilles et d'acariens et pour mesurer les caractères associés à la résistance.

2) Identifier les caractères spécifiques en relation avec la croissance des populations d'acariens.

3) Déterminer si ces caractères sont héréditaires.

4) Renforcer ces caractères par un élevage sélectif.

5) Regrouper les composantes de la résistance dans des abeilles productives et résistantes aux acariens. 
Dans cet article on entend par résistance à $V$. jacobsoni la sélection chez les abeilles de caractères qui vont retarder la croissance de la population d'acariens établie dans la colonie. Lors du criblage initial des caractères, nous avons utilisé des reines fécondées par un seul mâle. Nous pensons que cela a permis de détecter aussi des caractères peu fréquents. Les caractères au niveau de la colonie auraient pu être cachés si les reines avaient été fécondées par plusieurs mâles. Notre approche décrit la croissance de la population d'acariens au sein d'une colonie d'abeilles par l'équation : $P_{1}(a b)^{n}=$ $P_{2}$, où $P_{1}$ et $P_{2}$ sont les populations initiale et finale d'acariens, $a$ la variation de la population tant que les acariens sont dans les cellules de couvain, $b$ la variation quand ils sont hors des cellules de couvain et $n$ le nombre de cycles reproducteurs de l'acarien. L'équation est valable pour une colonie qui a un apport régulier en couvain d'ouvrières de façon à permettre la reproduction de l'acarien. Seules les femelles adultes d'acariens sont comptées et toutes les mesures sont des moyennes pour la colonie. En comparant les taux de croisssance des populations d'acariens de chaque colonie $\left(P_{2} / P_{1}\right)$, on peut déterminer la croissance réelle dans chaque colonie. Les valeurs $a, b$ et $n$ peuvent alors expliquer comment la population d'acariens est passée de $P_{1}$, à $P_{2}$ en termes de composantes mesurables du cycle reproducteur de l'acarien. Les variations de la population d'acariens doivent se refléter dans une ou plusieurs de ces composantes. Les caractères spécifiques des abeilles (qui sont la base de la sélection) peuvent alors être associés à l'une de ces trois composantes. Quand plusieurs caractères spécifiques agissent sur une même composante (par exemple. la suppresssion de la reproduction de l'acarien et le comportement hygiénique), leur effet combiné n'est pas nécessairement additif ni bénéfique. $\mathrm{Si}$ en revanche un même caractère spécifique agit en même temps sur différentes composantes, ceux-ci se combineraient probable- ment pour donner une colonie ayant une résistance accrue à $V$. jacobsoni.

Jusqu'ici notre sélection s'est concentrée sur un caractère, la suppression de la reproduction de l'acarien, qui provoque la non reproduction des acariens qui pénètrent dans les cellules de couvain. Sur la base de ce seul caractère héréditaire, nous avons produit des colonies dans lesquelles la population d'acariens décline durant une période test de $70 \mathrm{j}$. Deux autres caractères héréditaires, le comportement hygiénique et la proportion d'acariens sur le couvain, peuvent avoir aussi une importance pour la sélection d'abeilles résistantes. (C) Inra/DIB/AGIB/ Elsevier, Paris

\section{Apis mellifera / Varroa jacobsoni / population resistante / élevage sélectif}

\section{Zusammenfassung - Selektion von Honigbienen auf Resistenz gegen Varroa} jacobsoni. Dieser Beitrag befaßt sich mit Methoden zur Selektion von Honigbienen (Apis mellifera) auf Resistenz gegen den Befall durch Varroa jacobsoni Oudemans. In der Folge wird ein Zuchtplan beschrieben, der innerhalb jedes auf der Messung von Volkseigenschaften fußenden Selektionsprogramms wirkungsvoll angewendet werden kann.

1) Entwicklung von Methoden zur Erfassung der Populationen von Bienen und Milben und zur Messung der mit Resistenz verbundenen Eigenschaften.

2) Identifizierung spezifischer mit dem Anwachsen der Varroapopulationen in Beziehung stehender Eigenschaften.

3) Ermittlung, ob diese Eigenschaften vererbbar sind.

4) Verstärkung dieser Eigenschaften durch selektive Zucht.

5) Vereinigung der Resistenzkomponenten in produktiven, milbenresistenten Bienenlinien.

In diesem Bericht wird Varroaresistenzzucht als Selektion der Honigbienen auf Eigenschaften verstanden, die das Anwachsen 
von Varroapopulationen in den Völkern verlangsamen. In den anfänglichen Untersuchungen zum Auffinden von Resistenzeigenschaften benutzten wir Königinnen, die von nur einem Drohn besamt waren. Wir gehen davon aus, da $\beta$ hierdurch auch weniger häufige Eigenschaften ermittelt werden können. Diese Volkseigenschaften könnten verdeckt werden, wenn die Königinnen mit mehreren Drohnen verpaart sind. Unser Ansatz beschreibt das Wachstum von Varroapopulationen in den Bienenvölkern unter Verwendung der Formel $P_{1}(a b)^{n}=P_{2}$. Hierbei sind $P_{1}$ und $P_{2}$ die Milbenpopulation zu Anfang und am Ende, $a$ die Änderung der Population solange die Milben in den Brutzellen sind, $b$ die Änderung außerhalb der Brutzellen und $n$ die Anzahl von Reproduktionszyklen der Milben. Diese Gleichung beschreibt das Anwachsen einer Milbenpopulation mit einem konstanten Angebot an Brutzellen zur Vermehrung. Es werden nur die erwachsenen Milben gezählt, und alle Messungen sind Mittelwerte für die Völker. Durch Ermittlung des tatsächlichen Anwachsens der Milbenpopulation in jedem Volk kann die Zuwachsrate der Milbenpopulationen $\left(P_{2} / P_{1}\right)$ ermittelt werden. Die Werte von $a, b$, und $n$ können dann erklären, auf welche Weise die Milbenpopulation sich in Bezug auf meßbare Komponenten des Reproduktionszyklus der Varroamilben von $P_{1}$ nach $P_{2}$ entwickelt hat. Änderungen der Varroapopulation müssen auf eine oder mehrere dieser Komponenten zurückzuführen sein. Spezifische Eigenschaften der Bienen (die Grundlage der Selektion) können dann mit einer dieser drei Komponenten in Verbindung gebracht werden. Falls mehrere Eigenschaft eine dieser Komponenten beeinflussen (beispielsweise wirken sich eine Unterdrückung der Milbenreproduktion und das hygienische Verhalten beide auf $a$ aus) mu $\beta$ sich ihr kombinierter Effekt nicht notwendigerweise additiv oder günstig verhalten. Falls dagegen eine einzelne Eigenschaft verschiedene dieser Komponenten gleichzeitig beeinflu $\beta$ t, würden diese kombiniert mit hoher Wahrscheinlichkeit zu erhöhter Resistenz gegenüber Varroa jacobsoni führen.

Zur Zeit hat sich unsere Selektion auf eine einzelne Eigenschaft konzentriert, die Unterdrückung der Vermehrung der Milben. Dies führt dazu, da $\beta$ Milben nicht reproduzieren, nachdem sie eine Brutzelle befallen haben. Auf Grundlage dieser einzelnen erblichen Eigenschaft haben wir Völker erzeugt, in denen die Milbenpopulation über einen Zeitraum von 70 Tagen abnimmt. Zwei weitere Eigenschaften, das hygienische Verhalten sowie der Anteil der in der Brut befindlichen Milbenpopulation könnten ebenfalls wichtig sein, um Honigbienen auf Resistenz gegen Varroamilben zu selektieren. $($ Inra/ DIB/AGIB/Elsevier, Paris

\section{Apis mellifera / Milben / Varroa jacobsoni / Populationen / Selektionszucht}

\section{REFERENCES CITED}

[1] Anderson D.L.. Non-reproduction of Varroa jacobsoni in Apis mellifera colonies in Papua New Guinea and Indonesia, Apidologie 25 (1994) 412-421.

[2] Bienefeld K., Factors affecting duration of the postcapping period in brood of the honey bee (Apis mellifera cannica). J. Apic. Res. 35 (1996) $11-17$.

[3] Boecking O., Ritter W., Grooming and removal behaviour of Apis mellifera intermissa in Tunisia against Varroa jacobsomi, J. Apic. Res. 32 (1993) $127-134$.

[4] Boecking O., Rath W., Drescher W., Grooming and removal behavior - strategies of Apis mellifera and Apis cerana bees against Varroa jacobsoni, Am. Bee J. 133 (1993) 117-119.

[5] Büchler R., Varroa tolerance in honey bees occurrence, characters and breeding, Bee World 75 ( 1994) 54-70.

[6] Büchler R., Drescher W., Variance and heritability of the capped developmental stage in European Apis mellifera $\mathbf{L}$ and its correlation with increased Varroa jacobsoni Oud. infestation, J. Apic. Res. 29 (1990) 172-176.

[7] Büchler R., Drescher W., Tornier I., Grooming behaviour of Apis cerana, Apis mellifera and Apis dorsata and its effects on the parasitic mites Varroa jacobsoni and Tropilaelaps clareae, Exp. Appl. Acarol. 16 (1992) 313-319.

[8] Camargo J.M.F., Gonçalves L.S., Manipulation procedures in the technique of instrumental 
insemination of the queen honey bee, Apidologie 2 (1971) 239-246.

[9] Camazine S., Factors affecting the severity of Varroa jacobsomi infestations on European and Africanized honey bees, in: Needham G., Page R.E. Jr, Delfinado-Baker M., Bowman C. (Eds.), Africanized Honey Bees and Bee Mites, Ellis Horwood Ltd., Chichester, 1988, pp. 444-451.

[10] Collins A.M., Quantitative Genetics, in: Rinderer T.E. (Ed.), Bee Genetics and Breeding, Academic Press, Orlando, 1986, pp. 283-304.

[11] Danka R.G., Rinderer T.E., Kuznetsov V.N., Delatte G.T., A USDA-ARS project to evaluate resistance to Varroa jacobsoni by honcy bees in far-eastern Russia, Am. Bee J. 135 (1995) 746-748.

[12] DeJong D.. Egea Soares A.E., An isolated population of Italian bees that has survived Varroa jacobsoni infestation without treatment for over 12 years, Am. Bee J. 137 ( 1997) 742-745.

[13] Delfinado-Baker M., Rath W., Boecking O.. Phoretic bee mites and honeybee grooming behavior, Int. J. Acarol. 18 (1992) 315-322.

14] Donzé G., Herrmann M., Bachofen B., Guerin P.M., Effect of mating frequency and brood cell infestation rate on the reproductive success of the honeybee parasite Varroa jacobsoni, Ecol. Entomol. 21 (1996) 17-26.

[15] Eguaras M., Marcangeli J., Oppedisano M., Fernandez N., Seasonal changes in Varroa jacobsoni Oud. reproduction in temperate climates of Argentina, BeeScience 3 (1994) 120-123.

[16] Eguaras M., Marcangeli J., Oppedisano M., Fernandez N., Mortality and reproduction of Varroa jacobsoni in resistant colonies of bees (Apis mellifera) in Argentina, BeeScience 3 (1995) 174-178.

[17] Fries I., Camazine S., Sneyd J., Population dynamics of Varroa jacobsoni: a model and a review, Bee World 75 (1994) 5-28.

[18] Fries I., Huazhen W., Wei S., Jin C.S., Grooming behavior and damaged mites (Varroa jacobsoni) in Apis cerana cerana and Apis mellifera ligustica, Apidologie 27 (1996) 3-11.

[19] Fuchs S., Nonreproducing Varroa jacobsoni Oud. in honey bee worker cells - status of mites or effect of brood cells?, Exp. Appl. Acarol. 18 (1994) 309-317.

[20] Fuchs S., Muller K., Invasion of honeybee brood cells by Varroa jacohsoni in relation to the age of the larvae, in: Cavalloro R. (Ed.), European Research on Varroatosis Control, A.A. Balkema, Rotterdam, 1988, pp. 77-79.

[21] Fuchs S., Langenbach K., Multiple infestation of Apis mellifera L. brood cells and reproduction in Varroa jacobsoni Oud., Apidologie 20 (1989) 257-266.

[22] Gilliam M., Taber III S., Richardson G.V., Hygienic behavior of honey bees in relation to chalkbrood disease, Apidologie 14 (1983) 29-39.
[23] Guzman-Novoa E., Sanchez A., Page R.E. Jr, Garcia T., Susceptibility of European and Africanized honeybees (Apis mellifera L.) and their hybrids to Varroa jacobsomi Oud., Apidologie 27 (1996) 93-103.

124| Harbo J.R., Breeding honey bees (Hymenoptera: Apidae) for more rapid development of larvae and pupae, J. Econ. Entomol. 85 (1992) 2125-2130.

[25] Harbo J., Evaluating colonies of honey bees for resistance to Varroa jacobsoni, BeeScience 4 , (1996) 100-105

[26] Harbo J.R., The value of single-drone inseminations in selective breeding of honey bees, in: Connor L., Hoopingarner R. (Eds.), Apiculture for the 21 st Century, Wicwas Press, Cheshire, CT, 1999, pp. 1-5.

127] Harbo J.R., Harris J.W., Heritability in honey bees (Hymenoptera: Apidae) of characteristics associated with resistance to Varroa jacobsoni (Mesostigmata: Varroidae), J. Econ. Entomol. (1999) in press.

[28] Harbo J.R., Harris J.W., Comparing colonies with queens inseminated with semen from one or six drones, Am. Bee J. (1999) in press.

[29] Harbo J.R., Hoopingarner, R.W., Honey bees (Hymenoptera: Apidae) in the United States that express resistance to Varroa jacobsoni (Mesostigmata: Varroidae), J. Econ. Entomol. 90 (1997) 893-898.

[30] Harris J.W., Harbo J.R., Low sperm counts and reduced fecundity of mites in colonies of honey bees (Hymenoptera: Apidae) resistant to Varroa jacobsoni (Mesostigmata: Varroidae), J. Econ. Entomol. 92 (1999) 83-90.

131] Ifantidis M.D., Parameters of the population dynamics of the Varroa mite on honeybees, J. Apic. Res. 23 (1984) 227-233.

132) Ifantidis M.D., Some aspects of the process of Varroa jacobsoni entrance into honey bee (Apis mellifera) brood cells, Apidologie 19 (1988) 387-396.

[33] Kulincevic J.M., Rinderer T.E., Breeding honey bees for resistance to Varroa jacobsoni: analysis of mite population dynamics, in; Needham G., Page R.E. Jr, Delfinado-Baker M., Bowman C. (Eds.), Africanized Honey Bees and Bee Mites, Ellis Horwood Ltd., Chichester, 1988, pp. 434-443.

[34] Kulincevic J.M., Rinderer T.E., Urosevi D.J., Seasonality and colony variation of reproducing and non-reproducing Varroa jacobsoni females in western honey bee (Apis mellifer worker brood, Apidologie 20 (1988) 173-180.

[35] Lush J.L., Animal Breeding Plans, Iowa State University, Ames, 1945.

[36] Marcangeli J.A., Eguaras M.J., Fernandez N.A., Reproduction of Varroa jacobsoni (Acari: Mesostigmata: Varroidae) in temperate climates of Argentina, Apidologie 23 (1992) 57-60. 
[37] Martin S.J., Ontogenesis of the mite Varroa jacobsoni Oud. in worker brood of the honeybee Apis mellifera $\mathrm{L}$. under natural conditions, Exp. Appl. Acarol. 18 (1994) 87-100.

[38] Martin S.J., Holland K., Murray M., Non-reproduction in the honeybee mite Varroa jacobsoni, Exp. Appl. Acarol. 2 1(1997) 539-549.

[39] Message D., Gonçalves L.S., Effect of the size of worker brood cells of Africanized honey bees on infestation and reproduction of the ectoparasitic mite Varroa jacobsoni Oud., Apidologie 26 (1995) 381-386.

[40] Moosbeckhofer R., Fabsicz M., Kohlich A., Untersuchnungen über die Abhängigkeit der Nachkommensrate von Varroa jacobsoni Oud. vom Befallsgrad der Bienenvölker, Apidologie 19 (1988) 181-208.

[41] Moretto G., Gonçalves L.S., De Jong D., Heritability of Africanized and European honey bee defensive behavior against the mite Varroa jacobsoni, Rev. Bras. Genet. 16 (1993) 71-77.

[42] Moritz R.F.A., Heritability of the postcapping stage in Apis mellifera and its relation to varroatosis, J. Hered. 76 (1985) 267-270.

[43] Moritz R.F.A., Hänel H., Restricted development of the parasitic mite Varroa jacobsoni Oud. in the Cape honeybee Apis mellifera capensis Esch, Z. Angew. Entomol. 97(1984) 91-95.

[44] Moritz R.F.A., Jordan M., Selection of resistance against Varroa jacobsoni across caste and sex in the honeybee (Apis mellifera L., Hymenoptera: Apidae), Exp. Appl. Acarol. 16 (1992) 345-353.

[45] Morse R.A., Gonçalves L.S., Varroa disease, a threat to world beekeeping, Glean. Bee Cult. 107 (1979) 179-181, 202.

[46] Otten C., Factors and effects of a different distribution of Varroa jacobsoni between adult bees and bee brood, Apidologie 22 (1991) 466.

[47] Otten C., Fuchs S., Seasonal variations in the reproductive behaviour of Varroa jacobsoni in colonies of Apis mellifera carnica, A. m. ligustica and A. m. mellifera, Apidologie 21 (1990) 367-368.

[48] Peng Y.S., The resistance mechanism of the Asian honey bee (Apis cerana) to the mite Varroa jacobsoni, in: Needham G., Page R.E. Jr, Delfinado-Baker M., Bowman C. (Eds.), Africanized Honey Bees and Bee Mites, Ellis Horwood Ltd., Chichester, 1988, pp. 426-429.

[49] Peng Y.S., Fang Y., Xu S., Ge L., The resistance mechanism of the Asian honey bee, Apis cerana Fabr., to an ectoparasitic mite, Varroa jacobsoni Oudemans, J. Invertebr. Pathol. 49 (1987) $54-60$.
150] Rath W., Drescher W., Response of Apis cerana Fabr. toward brood infested with Varroa jacobsoni Oud. and infestation rate of colonies in Thailand, Apidologie 21 (1990) 31 1-321.

[51] Rinderer T.E., Kuznetsov V.N., Danka R.G., Delatte G.T., An importation of potentially varroa-resistant honey bees from far-eastern Russia, Am. Bee J. 137 (1997) 787-789.

[52] Ritter W., De Jong D., Reproduction of Varroa jacobsoni Oud. in Europe, the Middle East and tropical South America, Z. Angew. Entomol. 98 (1984) 55-57.

153] Rosenkranz P., Engels W., Infertility of Varroa jacobsoni females after invasion into Apis mellifera worker brood as a tolerance factor against varroatosis, Apidologie 25 (1994) 402-4 Il.

[54] Rosenkranz P., Tewarson N.C., Singh H. Engels W., Differential hygienic behaviour towards Varroa jacobsoni in capped worker brood of Apis cerana depends on alien scent adhering to the mites, J. Apic. Res. 32 (1993) 89-93.

[55] Rothenbuhler W.C., A technique for studying genetics of colony behavior in honey bees, Am. Bee J. 100 (1960) 176, 198

[56] Rothenbuhler W.C., Behaviour genetics of nest cleaning in honey bees. I. Responses of four inbred lines to disease-killed brood, Anim. Behav. 12 (1964) 578-583.

[57] Rothenbuhler W.C., Thompson V.C., Resistance to American foulbrood in honey bees. I. Differential survival of larvae of different genetic lines, J. Econ. Entomol. 49 (1956) 470-475.

[58] Ruttner F., Marx G., Beobachtungen über eine mögliche Anpassung von Varroa jacobsoni an Apis mellifera L. in Uruguay, Apidologie 15 (1984) 43-62.

[59] Ruttner F., Hänel H., Active defense against Var roa mites in a Carniolan strain of honeybee (Apis mellifera caarnica Pollmann), Apidologie 23 (1992) 173-187.

[60] Spivak M., Honey bee hygienic behavior and defense against Varroa jacobsoni, Apidologie 27 (1996) 245-260.

[61] Spivak M., Gilliam M., Facultative expression of hygienic behaviour of honey bees in relation to disease resistance, J. Apic. Res. (1993) 147-157.

[62] Stürmer M., Rosenkranz P., Die Bedeutung der phoretischen Phase für die Oogenese von Varroa jacobsoni, Apidologie 25 (1994) 453455

163] Trouiller J., Arnold G., Le Conte Y., Masson C., The production of kairomones of Varroa jacobsoni and brood pheromones by honey bee larvae, in: Connor L., Rinderer T., Sylvester H., Wongsiri S. (Eds.), Asian Honey Bees and Bee Mites, Wicwas Press, Cheshire, CT, 1993. pp. $447-453$. 